\title{
Penta Helix Strategy in Rural Tourism (Case Study of Tugu Utara Bogor)
}

\author{
R.M.W. Agie Pradhipta ${ }^{1,}{ }^{*}$, Pusparani ${ }^{1}$, and Fifi Nofiyanti ${ }^{1}$ \\ ${ }^{1}$ Hospitality and Tourism, STP Trisakti, IKPN Bintaro, Jakarta Selatan, 12330, Indonesia.
}

\begin{abstract}
This study aims to determine the extent of the implementation of the penta helix collaboration strategy in rural tourism (case study in the Tugu Utara of Bogor). The research method used in this study is qualitative by taking data using interviews, surveys and observations, and using data triangulation to strengthen this research. The results of this study stated that to foster sustainable rural tourism requires the involvement of elements that have the same tasks and contributions in developing a sustainable rural tourism program. Tugu Utara Village applies the penta helix strategy in the concept of planning, implementing and developing a sustainable rural tourism industry. The penta helix elements involved in Tugu Utara Village include: 1) the role of the village government as a regulator and facilitator, 2) the role of community institutions as managers of rural tourism programs, 3) the role of academics as a companion and source of knowledge, 4) the role of the world industry and business world as partners that grow the business and economic opportunities of rural communities; and 5) the function of social media in publicizing and promoting rural tourism industry products.
\end{abstract}

\section{Introduction}

Tourism has become a destination for people to enjoy holidays with friends, relatives and family. Even in the world of education, study tours are held and delivered to tourist destinations. Various communities, organizations, and other associations also organize tours to tourist destinations. The current conditions related to the Covid 19 pandemic have made the tourism industry decline. But surely tourism will bounce back after this pandemic ends.

Several tourist villages were formed in various regions. Tugu Utara Village, located in Bogor Regency, is directing its area to become a tourist village. Based on news information from [10], Roy expressed his pride in Tugu Utara Village for his achievements in representing Bogor Regency in the village competition at the West Java Province level. "Tugu Utara Village has undergone a rigorous selection process, I am proud of its achievement," he said.

The incessant government in encouraging the growth of tourist villages is one of the government's efforts to improve people's welfare starting from rural areas [2]. The level of welfare of rural communities is relatively lower than those of people living in cities. The percentage of poverty in rural areas in 2017 still shows a high number. The percentage of

\footnotetext{
* Corresponding author: agiepradhipta@stptrisakti.ac.id
} 
poverty in rural areas was recorded at 13.96 percent, while in urban areas it was only 7.7 percent.

This research seeks to provide assistance to the people of Tugu Utara Village, that the role of the penta helix is very much needed. Academics, practitioners, and the community who will develop and build the village into a tourist village, need a synergistic role of the helix penta.

The development of tourist destinations cannot stand alone, it requires strategies and supports one another. The application of the penta helix is needed in developing tourist destinations. This will facilitate the coordination, implementation and evaluation of the programs being organized. The penta helix strategy between various tourism activists is needed for the implementation of the development of tourist destinations. In this study, to determine the Strategy for the Implementation of Penta Helix in the Development of Tugu Utara Village as a Tourist Destination in Bogor Regency Post-Covid 19. This research was conducted to determine the implementation of the Penta Helix strategy.

This research is based on a discussion conveyed by the community of the village of Tugu Utara Puncak Bogor, related to the absence of changes that have occurred in society related to the tourism industry and the economy. The peak area of Bogor includes many tourist attractions and there is a high interest in tourists to come there. However, there is a problem in society what factors make the community less direct. Because the owner and manager of the tour there are also private. Community disobedience about management practices makes for a lack of significant change. So that researchers find the root of the problem with the penta helix. Looking for data on the role of the penta helix whether or not they have collaborated in Tugu Utara Village. Because to achieve sustainable tourism, the role of the penta helix is needed.

The urgency of this research is to determine the Strategy for the Implementation of Penta Helix in the Development of Tugu Utara Village as a Tourist Destination in Bogor Regency.

\section{Literature Review}

Based on the research results of [9], the development of tourism in the city of Semarang uses the pentahelix model, which involves 5 (five) elements, namely: academics, government, community, business, and mass media. From the research results it is known that community elements (tourism activists) have a very strategic role, namely a group that is able to coordinate all elements in the development of tourism in the city of Semarang.

The Penta Helix element was originally a Triple Helix with elements of Academics, Business Sector, Government, which was then added with one element, Civil Society (or Communities in this study), to become a Quadruple Helix, to accommodate people's perspectives, in this case a "media and culture-based society" which has also become an integral part of innovation in the $21^{\text {st }}$ century today [3]. Furthermore, the Communities element opens opportunities for interdisciplinary configuration and networking, and frees the concept of "innovation" from just economic considerations and goals, but also involves creativity as part of the process of producing knowledge and innovation.

Realizing this development model must of course be realized synergistically with all parties, especially in the form of Penta Helix collaboration, including the government, related Regional Apparatus Organizations (OPD), the community (community), the private sector to universities and media. The partnership is built according to the existing main duties and functions by eliminating sectoral egos between each sector.

The Pentahelix model was first launched by former tourism minister of Indonesia, as issued in the Republic of Indonesia Ministerial Regulation Number 14 of 2016 concerning Guidelines for Sustainable Tourism Destinations. Pentahelix model is one of the references 
to develop synergy between related agencies in order to be optimal in order to achieve the goals of tourism development [4].

The 'Penta-Helix model' is based on five types of stakeholders: business, public administration, local residents, the knowledge sector and capital. This model is especially useful for multi-stakeholder problem areas where stakeholders represent different interests on a site or problem.
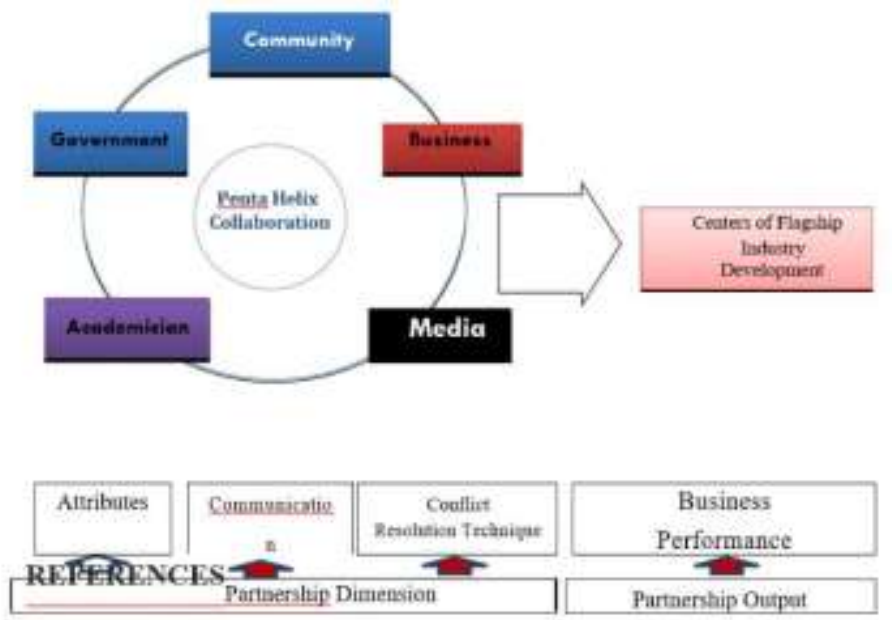

Source: [3]

Fig.1. The Penta Helix Theory

Penta helix according to [7] is an extension of the triple helix strategy by involving various elements of the community or non-profit organizations to realize innovation. Through synergistic collaboration, it is hoped that innovation can be realized that is supported by various resources that interact synergistically.

Based on [8] concerning Tourism, namely tourism destination areas, hereinafter referred to as Tourism Destinations, is a geographical area located in one or more administrative areas in which there are tourist attractions, public facilities, tourism facilities, accessibility and communities are interrelated and complement the realization of tourism. The potential for a tourism location actually has various interdependent elements, namely: attractions, facilities, ilnfrastructure, transportation, hospitality. These existing and interrelated elements are indispensable so that tourists can have a satisfying experience. The meaning of these five elements is:

\section{Attractions}

Attractions is the center of a tourism industry. According to the definition of attraction, it can attract tourists who want to visit it. A primary destination is a place or location that really attracts the attention of tourists and is the main object of their journey. Usually these locations can satisfy the needs or interests of tourists for a few days or longer. A secondary destination or stopover destination is a place of interest or need to be visited.

\section{Amenities}

Although the attractions attract tourists from their homes or places of residence, facilities are needed to serve them during the trip. Facilities tend to support rather than encourage growth and tend to develop at the same time or after attractions develop. An attraction can also be a facility.

During their stay in a place far from home, tourists should sleep, eat and drink. Lodging facilities vary from hotels and international standards to camping facilities homes of 
relatives and friends. Lodging costs are usually one-fifth or a quarter of the total tourist expenditure. Provision of lodging facilities with the appropriate number and quality is very important for the success of a tourist destination. The types of lodging facilities available are mainly determined by the characteristics of the tourism market segment that is being netted.

\section{Infrastructure}

Attractions and facilities cannot be reached easily without basic infrastructure. Infrastructure includes all below and above ground construction of an area or area. These include: irrigation systems, communication networks, health facilities, terminals, transport terminals, power and energy sources, sewage and water disposal systems, roads or highways, security systems.

There are criticisms that tourism is too dependent on well-developed infrastructure. However, there are certain destination areas, especially those newly introduced or introduced that can meet the needs of tourists without a perfect infrastructure system. Limited roads may be an advantage for certain types of tourism. If the longer a destination is attractive, the more tourists will be, the additional number of tourists itself will encourage infrastructure development. In other cases, the opposite is true. Infrastructure development is necessary to encourage tourism development. The infrastructure of a tourism area is actually enjoyed or partly used by tourists and the people who live there. Hence infrastructure is almost always the responsibility of the government. Fulfillment or creation of infrastructure is a way to create a comfortable atmosphere for tourism development.

\section{Transportation}

There are several problems related to the transport facilities and terminals. In general, there is almost no coordination among the three types of transportation, such as buses, trains and airplanes. Also the standards and regulations that apply to this type of transport are less consistent. For example, direction signs and information signs that are difficult to read. Traffic signs must be uniform throughout the system. Verbal announcements were hard to hear.

At airports, passengers often have to walk long distances from gate to gate within the airport. Trains, the existing facilities at the station are inadequate and high crime occurs at large stations in some train stations, information and map services are not available.

\section{Hospitality and safety}

Tourists are in an unfamiliar environment, so certainty or assurance regarding security is very important. In particular, for passengers who have traveled far to a foreign country, the image of their destination may be given an unfavorable impression, for example, the image in Thailand which is being discussed on television makes tourists afraid and does not feel safe and comfortable visiting the place. This will be an anxiety for tourists. The situation that is less safe and comfortable in this allows people to avoid visiting a place, so security and protection is needed that must be considered and provided so that potential tourists feel safe before and during the trip.

Assessing Penta Helix as cross-sector collaboration in the village tourism, the study provides a model of how Penta helix actors role in village tourism development and management [5]. The central actor of the Penta helix model is a community who will manage the village with its characteristics. They will be responsible for the value of the village not only in the context of attraction but also the social and culture elements. The second core actor will be the government. As a policy maker, government has an authority to preserve and maintain the development of the tourism village. Beside provide some fund and assistance to the village, the government is also performing a function as facilitator and 
mediator to other three stakeholders in Penta helix they are; business, academics, and social entrepreneur.

\section{Research Methods}

The research method used is a qualitative approach. This type of descriptive research is writing that contains a description of an object as there is a certain time, to describe in detail a series of data obtained through observations and interviews that have been conducted.

Research instruments use interviews, surveys, and observation's to obtain accurate and clear information. The informants were determined using the Snowball technique, namely tourism activists in Tugu Utara Village, Pokdarwis Tugu Utara Village, and local government. This research was conducted for 2 months in Tugu Utara Village. The number of respondents in this study was 20 people, consisting of the main respondents, namely residents of North Tugu Village (tourism village manager), and supporting respondents, namely the head of North Tugu Village. Data validation used data triangulation by inviting several expert sources. The phenomenon observed is the cooperation model used in tourism development in the village of North Tugu.

Qualitative research is intended to record all phenomena seen and heard and read through interviews or not, field notes, photos, video tapes, personal documents or memos, official documents or not, etc., and researchers must compare, combine, saying that in creating orchestration and ensuring the quality of activities, facilities, services, creating experiences and value benefits of tourism in order to provide benefits and benefits to the community and the surrounding environment, it is necessary to encourage the tourism system through optimizing the role of business (business), abstracting government, and draw a conclusion. Furthermore, data analysis can be carried out through data organizing, by sorting it into manageable units, synthesizing it, looking for and finding patterns, finding what is important and what is learned and deciding what can be used as findings and conclusions [1].

\section{Research Result}

\subsection{Tourism Village Tugu Utara Bogor}

Tugu Utara village is located in Bogor, West Java. The village is being developed into a tourist village. Asep Ma'mun Nawawi, SH. as the Head of the North Tugu Village who also doubles as the Head of Village Volunteers Against Covid-19, again carried out socialization activities for handling the spread of the Corona or Covid 19 Virus. After conducting socialization in $3 \mathrm{RW}$ areas. The Village Head is also accompanied by Covid-19 Handling partners. North Tugu Village has an area of $\pm 1,703$ hectares divided into 3 (three) hamlets, 6 (six) Rw and 24 (twenty four) RTs, the current population of North Tugu Village is 11,030 people consisting of 5,697 male and 5,333 female souls, with a total of 3,328 family heads. The population based on their livelihoods in the village of Tugu Utara Bogor are 648 farmers, 65 businessmen, 1 craftsman, 315 workers, 750 planters, 556 traders, 215 drivers, 5 TNI / POLRI people. Tugu Utara Village has a lot of tourism potential, such as Curug Kembar, Curug Cisuren, Setu Cikoneng, Sitamiang campsite, tea garden and Sitamiang site. 


\subsection{Destination Management Required Penta Helix System}

Managing destinations in Tugu Utara Village requires a system of cooperation in the management of several fields, namely tourism product management, management of cultural attractions and performing arts, environmental management, and management of the community's creative industry. The management of the four fields above needs to be done in synergy, so that the five elements of the destination (tourist attractions / attractions, amenities, accessibility, image, and prices) can be managed optimally. The success of the cooperation system program, Penta Helix is influenced by five other elements, starting from advocacy, policy, and budget support for the village government, followed by policy support in forming community institutions, tourism awareness groups. Followed by assistance to increase technical competence in the field of tourism carried out by academics. Support from the village government is urgently needed in the provision of facilities and infrastructure to carry out development activities for the tourism industry in the village. It is hoped that the role of the tourism awareness group in the village of North Tugu can carry out the function of planning the work program and running it.

\subsection{The Role of Penta Helix in Tugu Utara Village, Bogor}

The results of the research obtained from the village of North Tugu were obtained about the role of the helix in an effort to build tourist destinations in the village. Penta helix are the elements needed in building tourist destinations in the village. Research on the application of the penta helix has been conducted by several researchers. The village economic granary development model must of course be realized synergistically with all parties, especially in the form of Penta Helix collaboration, including the government, related Regional Apparatus Organizations (OPD), the community (community), private parties to universities and the media. The partnership is built in accordance with the existing main duties and functions by eliminating sectoral egos between each sector.

The penta helix elements involved in the village of North Tugu include:

\subsubsection{The role of the village government}

The role of village government as regulator and facilitator is at the village head government level. The village head oversees the community to carry out activities that function to increase the creativity and creative economy of the community. The village government provides policy support and budget assistance using village funds programmed in the RPJMD of Tugu Utara Village. Development of facilities and infrastructure to support tourism activities. Carrying out BIMTEK activities to increase community capacity in managing MSMEs related to the tourism program in Tugu Utara Village. The role of the government that has been carried out is the construction of basic facilities and infrastructure in the form of road access, basic facilities in several tourist objects, such as: the current lake. Development of performing arts attractions in the form of procurement of traditional musical instruments which is the role of the village government.

\subsubsection{The role of community institutions}

The role of community institutions as managers of the tourism village program created Pokdarwis which was named Dewi Amarta. In developing the potential of North Tugu village, the role of community organizations through Pokdarwis already exists, although it has not been developed significantly. This is because Pokdarwis in the village is only driven by a few people, namely 5 people. The community is not aware that they are 
together to build their village, because they also have jobs and livelihoods that must be done on a daily basis. Pokdarwis that has been built and active has participated in several trainings organized by MSMEs, village governments, provincial governments, and opportunities to increase knowledge from various sources.

\subsubsection{The role of academics}

Building the Development of Tugu Utara Village as a tourist destination in Bogor Regency requires many sectors, cooperation, and especially the role of academics. Academics as companion and knowledge resource for the village community. The role of academics as partners is those who understand the planning and development of tourist destinations to develop the village of Tugu Utara Bogor. The role of academics who accompany the village of Tugu Utara Bogor in an effort to develop tourist destinations, namely the Trisakti Tourism College campus. Activities that have been carried out by the village community with STP Trisakti in the form of community service lecturers who provide training to the community on human resources, tourism awareness, and homestays. The role of academics is carried out by the community of Tugu Utara Bogor village, namely with the GDE Gold Village Movement). The community obtains knowledge, guidance, and training related to MSMEs, village culinary delights, and strengthens community togetherness. In the activities held by academics, the public is interested and interested, so that many take part in these activities. The role of the village head in terms of development activities and providing knowledge to the community in his village is fully supported and assisted.

\subsubsection{The role of industry and business}

The role of industry and business is the synergy of involvement of the industrial world in terms of developing and standardizing the quality of processed products or the creativity of rural communities. Tugu Utara Village has implemented the role of the business world in the form of Cibulao coffee production. Village communities with coffee farmer groups have succeeded in developing a business activity. The village community already owns the Cibulao coffee shop, which is an outlet for non-timbeorest products originating from farmer groups assisted by the Regional ForestrySercvice branch.

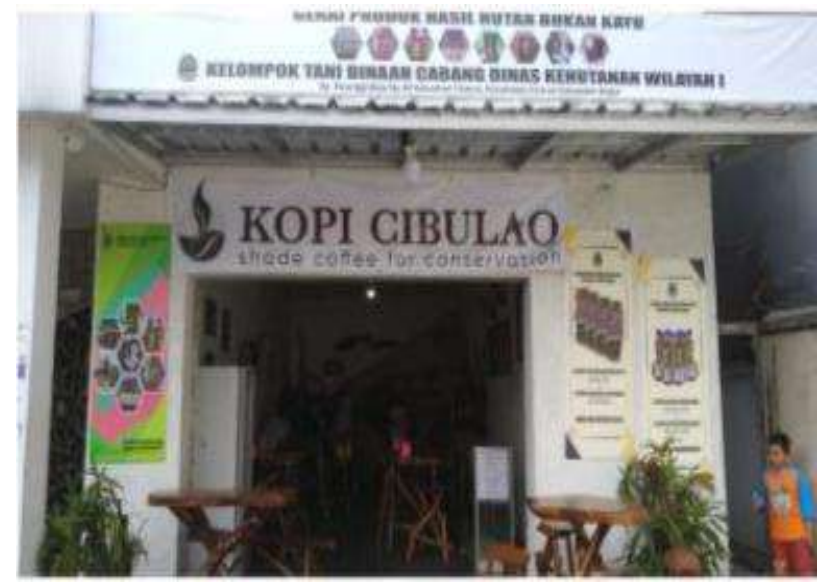

Fig. 1. Community Business World Tugu Utara Bogor 


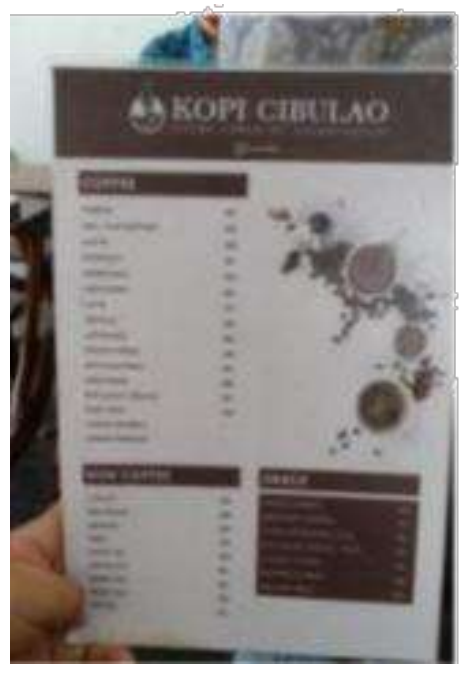

Fig. 2. Community Products at Cibulao coffee shop

\subsubsection{The role of social media}

The role of social media in the application of penta helix to the community of Tugu Utara village, Bogor is very much needed. Social media in publishing and promoting the products of the rural tourism industry. The role of the media acts as an expender and a means of contact to introduce tourism products and destinations in Tugu Utara Bogor. The media also plays a role in supporting publication, promotion and creating a brand image. Good and attractive products, without social media as promotion, are not known by consumers. The era of 4.0 and 5.0 in the world of technology is a daily necessity for people. Examples in several tourist destinations in the City and Regency of Bandung are known to the wider community through social media. Desa Tugu Bogor has social media, Facebook, Instagram, but their usage has not been updated. The village community already has the Tugu Utara Village website, but it only describes in general terms the village's geography. Potentials and tourist destinations on the website need to be provided with information and photos of the atmosphere of the destination, so that people who enjoy traveling can access them. Tugu Utara Village has a website http://tuguutara-cisarua.desa.id/first/artikel/124 , but social media to introduce tourist destinations in Tugu Utara Village, Bogor, have not been posted properly and attractively.

Based on the study of [6], it can be withdrawn some suggestions as follows: (1) sinergency pentahelix in tourism recovery in Karo District is the right strategy as a postdisaster rehabilitation program the Sinabung eruption. Multiple programs the proposed one will not be optimal if it is wrong one party does not play a maximum role by therefore, collaboration is absolutely necessary d natural restorer tourism in Karo District. (2) In addition, this study only focuses on inventory of tourism recovery common in Karo District

Based on previous research that the role of the penta helix is not functioning properly, the program of activities carried out for sustainable tourism will not run well.

\section{Conclusion}

The penta helix elements involved in Tugu Utara Village include: 1) the role of the village government as a regulator and facilitator, 2) the role of community institutions as managers of rural tourism programs, 3) the role of academics as a companion and source of 
knowledge, 4) the role of the world industry and business world as partners that grow the business and economic opportunities of rural communities; and 5) the function of social media in publicizing and promoting rural tourism industry products. Subsequent research can review which elements of the penta helix have less role in realizing sustainable tourism.

\section{References}

1. Bungin, Burhan. Metodologi Penelitian Kualitatif. Jakarta: Raja Grafindo Persada. (2008)

2. Febriana, A.Y.E and Pangestuti E., Jurnal Administrasi Bisnis (JAB) 61 (2018)

3. Muhyi, H. A., Chan, A., Sukoco, I., \& Herawaty, T., The Penta Helix Collaboration Model in Developing Centers of Flagship Industry in Bandung City, Review of Integrative Business and Economics Research, 61, 412-417 (2017)

4. Nainggolan, M., International Journal of Linguistics, Literature and Culture, 62 (2020)

5. Putra, Trisna. A Review on Penta Helix Actors In Village Tourism Development And Management. JBHOST. Vol 05 Issue 01. ISSN.63-75 ISSN 2527-9092 63. (2019).

6. Rizkiyah, P. et.al, Jurnal IPTA, 72 (2019).

7. Sturesson. Elof, Lindmark, Adam, "Collaboration for Innovation - A Study in the Öresund Region”, Sweden: Lund University Libraries, (2009).

8. Undang-Undang RI No.10 tahun 2009

9. Yuniningsih, Tri, et.al, Journal of Public Sector Innovation, 32, 84-93 (2019)

10. https://bogorkab.go.id/post/detail/provinsi-jawa-barat-nilai-desa-tugu-utara-kecamatancisarua. Diunduh 3 Juli. Pukul 10.03 (2020) 